\title{
DOSTOEVSKY AND STENDHAL'S SYNDROME
}

\author{
Edson José Amâncio ${ }^{1}$
}

\begin{abstract}
Stendhal's syndrome occurs among travelers when they encounter a work of art of great beauty. It is characterized by an altered perception of reality, emotional disturbances, and crises of panic and anxiety with somatization. The patient profile described originally for this syndrome was of particularly sensitive individuals who were admirers of works or art: artists, poets, writers and art students, among others. The Russian writer Fyodor Mikhailovich Dostoevsky suffered from epilepsy and there is evidence that he presented the symptoms of Stendahl's syndrome while contemplating some works of art, particularly when viewing Hans Holbein's masterpiece, Dead Christ, during a visit to the museum in Basle.
\end{abstract}

KEY WORDS: Stendhal syndrome, Dostoevski, Hans Holbein dead Christ.

\section{Dostoiévski e a síndrome de Stendhal}

RESUMO - A síndrome de Stendhal foi descrita pela psiquiatra italiana Graziela Margherini, em 1989. Foi assim denominada em homenagem ao famoso escritor francês Stendhal que viveu na Itália grande parte da sua vida como diplomata. Stendhal descreveu as sensações que se apoderaram dele ao se deparar com algumas obras primas de pintores e escultores em Florença - vivências estranhas, por vezes acompanhadas de sintomas físicos, sensação de profunda emoção, seguida de um leve entorpecimento, desorientação têmporo-espacial momentânea, sudorese profusa e desrealização. Esse conjunto de sintomas, ocorridos durante a contemplação de uma obra de arte, foram catalogados por Graziela Magherini no hospital Santa Maria Nuova de Florença em 106 pacientes, todos eles viajantes que vieram a Florença pela primeira vez, passando a denominá-los síndrome de Stendhal. Com base nas reações do escritor russo Fiódor Mikhailovitch Dostoiévski diante do quadro $O$ Cristo Morto, de Hans Holbein, o jovem, num museu da Basiléia descritas por sua segunda esposa Anna Grigoriévna Sniktina, em dados biográficos e na análise do entusiasmo com que o príncipe Míschkin, personagem principal do romance $O$ ldiota, demonstra pelo quadro, na própria descrição que Dostoiévski fez dessa obra de arte, este autor propõe a ocorrência da síndrome no escritor russo diante da contemplação do quadro. Discute ainda a possibilidade de tais fenômenos serem manifestações críticas da epilepsia parcial complexa de que provavelmente Dostoiévski era portador.

PALAVRAS-CHAVE: síndrome de Stendhal, Dostoiévski, Hans Holbein, Cristo morto.

Stendhal's syndrome was first described by the Italian psychiatrist Graziella Magherini ${ }^{1}$ in 1989 , and was named in homage after Marie-Henri Beyle: Marie-Henri Beyle was better known as Stendhal, a French writer who lived in Italy.

Stendhal's diaries are full of notes refe ring to the famous works of art in Florence and in particular the emotions that took hold of him when viewing such works. Magherini compared these notes with the symptoms presented by 106 tourists interned in the Santa Maria Nuova hospital in Florence over a period of more than a decade and named the set of symptoms Stendhal's syndrome.

The present study makes a review of the feelings experienced and described by Stendhal in his diaries during the time he was living in Florence and gives evidence that the Russian writer Fyodor
Mikhailovich Dostoevsky presented similar symptoms, especially when contemplating the famous painting Dead Christ, by the German artist Hans Holbein, in the museum in Basle.

\section{METHOD}

Stendhal's diaries contained in his book Rome, Naples et Florence were consulted, particularly the annotations of 22 January 1817 when he went to see various works of art in Florence, as well as Graziella Magherini's book Sind rome di Stendhal. For the symptoms presented by Dostoevsky when viewing the painting Dead Christ, the diaries of the writer's second wife, Anna Grigorievna, and the biography of Dostoevsky written by Joseph Frank were consulted, as well as the novel The Idiot, in which Dostoevsky makes an extensive and detailed description of Holbein's painting.

${ }^{1}$ Neurosurgeon, Posgraduation Student, Federal University of São Paulo (EPM-UNIFESP), São Paulo SP, Brazil.

Received 20 December 2004, received in final form 14 July 2005. Accepted 18 August 2005.

Dr. Edson J. Amancio - Avenida Bartolomeu de Gusmão 174/42 - 11030-500 Santos SP - Brasil. E-mail: edson-amancio@uol.com.br 


\section{RESULTADOS}

Stendhal - On 22 January 1817, after visiting the Franciscan church of Santa Croce where several Italian artists, writers and scholars are buried, including the poet Vittório Alfieri, Michelangelo and Galileo, Stendhal noted in his diary: "There, to the right of the door, is Michelangelo's tomb; beyond this is Alfiere's tomb, by: I know of this great Italian figure. Then I notice Machiavelli's tomb and, in front of Michelangelo, there rests Galileo. Such men! What a magnificent collection! My emotion is so deep that it almost reaches piety. The melancholic religiousness of this church and its simple wooden vaulted arches, still unfinished: all this speaks vividly within my soul"'.

In the north transept of the church where Stendhal could see the cupola decorated with frescoes by Volterrano a seventeenth-century Florentine painter, his emotions overflowed almost into ecstasy: "Sitting on the step of a genuflection stool, with my eyes diverted from the pulpit to be able to contemplate the ceiling, Volterrano's Sibyls gave me perhaps the greatest pleasure that any painting had ever given me. (...) I reached the emotional state in which we experience the celestial feelings that only the beauties of art and sentiments of passion can offer. Upon leaving Santa Croce, my heart was beating irregularly (...), life was ebbing out of me and I went onwards in fear of swooning"2.

According to Graziella Magherini, the majority of the foreign tourists who were attended at the Santa Maria Nuova hospital presented acute psychological disturbances that lasted from two to eight days or longer. Such disturbances are characterized by two types of clinical manifestation: mental and psychosomatic. The mental take the form of disturbances of the sense of reality, described as feelings of strangeness or alienation; altered perception of sounds and colors; and the delirium of being persecuted in relation to the immediate environment. The psychosomatic symptoms reported include tachycardia, chest pains, weakness, sweating and sometimes stomach pains, each generally accompanied by anxiety and confusion'. The psychological profile of such patients is of single persons who are relatively young, sensitive, impressionable and traveling on their own (or perhaps with one other person), and they are coming into contact with great works of art without the mediation of a professional guide.

Dostoevsky - The Russian writer Fyodor Mikhailovich Dostoevsky (1821-1881), author of The Idiot,
Crime and Punishment, The Possessed and The Brothers Karamazov among others, suffered from epilepsy and probably presented partial epilepsy that was secondarily generalized with possible involvement of the temporal lobe ${ }^{3-10}$. These suppositions are supported by the testimonies of doctors who attended him, jottings by the writer's friends and relatives, and his own writings as well as by resorting to the characteristics of the epileptic crises described by the writer in the characters created in his novels, especially Helena in The Insulted and Humiliated, Prince Michkin in The Idiot, Kirilov in The Possessed and Smerdyakov in The Brothers Karamazov.

Dostoevsky published his first novel Poor Peo ple in 1843 when he was 23 years old. The book received enthusiastic support from the most important literary critic of that time, Vissarion Byelinsky, thus leading the youth author to immediate fame. In 1847 Dostoevsky was imprisoned in the Peter and Paul fort ress of St Petersburg for participating in clandestine meetings at the house of a professional agitator, Petrashevsky whose objective was the propagation of revolution and freeing of the serfs. After one year in prison, he received the sentence: death by firing squad in a public square. At the last minute, with the prisoners lined up and tied to posts, the penalty was commuted to exile in Siberia.

Dostoevsky stayed in Siberia for nine years; four as a common prisoner in the fort ress of Omsk and five as an ordinary soldier in the Semipalatinsk battalion. It was there he met his first wife, Maria Dmitrievna, the widow of a former public employee. In 1856, he obtained permission to return to Russia, living first in Tver and later in St Petersburg. He published The House of the Dead, a moving report of his own experiences in prison, which gained readers' sympathy and he resumed his abandoned literary relationships after almost ten years of exile ${ }^{11}$. After the death of his first wife in 1864, he married again within a few years, with Anna Grigorievna Sniktin, with whom he set off on a journey through Europe. On his way to Geneva he decided to take a small break in the journey and visit Basle. The object of the visit was to see the painting Dead Christ, by the German artist Hans Holbein the Younger, which he had heard about ${ }^{12}$.

Anna Grigorievna's testimony-According to Anna Grigorievna's diary, Dostoevsky behaved strangely when viewing Holbein's painting: "During the journey to Geneva, we stopped in Basle to visit the museum, where there was a painting that my husband had heard about. This was a pic- 
tu re by Hans Holbein, representing Christ after his inhuman marty rdom, now taken down from the c ross and in the process of decomposition. The vision of the tumescent face, full of bloody wounds, was terrible. The painting had an oppressive impact on Fyodor Mikhailovich. He remained standing in front of it as if stunned. And I did not have the strength to look at him - it was very painful for me, especially in my sickly state [of pregnancy] - and I went to other rooms. When I returned after fifteen or twenty minutes, I found him stuck in the same place, in front of the painting. His agit ated face presented a kind of fear, something that I had noted more than once before, in the first moments of an epileptic attack. I calmly took my husband by the arm, led him to another room and sat him down on a bench, expecting the attack at any moment. Thankfully this did not happen. He calmed down little by little and left the museum, but he insisted on going back there again to see this painting that had impressed him so much"13.

Dostoevsky described it in detail in the novel The Idiot. "The picture re $\mathrm{p}$ resents Christ just after having been taken down from the cross. I think that, as a rule, artists who paint Christ on the cross or after he was taken down, make a point of maintaining an extraordinary beauty on his face. They make efforts to preserve this beauty, even in his most terrible agonies. In the painting..., there is not the slightest vestige of this beauty. It portrays no more, in all its aspects, than the corpse of a man who en$\mathrm{d} u$ red infinite agony before dying crucified; who was stabbed, tort u red and flogged by the guard s and the people when he was carrying the cross on his shoulder and fell under its weight; and who after all this endured the agony of crucifixion, surviving for at least a further six hours (by my deduction). It simply portrays the face of a man who has just been taken down from the cross, i.e. still showing signs of warmth and life. There is still no rigidity, such that the expression of unfinished suffering is seen on the face of the now-dead man, as if he were still feeling it. (This was well achieved by the artist who made this painting). And the face has not been spared. It depicts a man's corpse well - what was once a man and shows the nature of a being whose time is over. Any man would be like this; it could not be otherwise after such suffering. (...) On the picture, the face is horribly macerated by blows and tumefaction, covered with hideous purple bruising; deformed; with the eyes dilated and lusterless. These are eyes whose whites give off a livid, half-glazed deathly light. And what is most strange is that, in looking at that corpse of a tortu red man, a specific and bizarre question is raised: if that body (and Christ must have been like that) were seen by his disciples, by those who would become his main apostles, by the women who followed him along the Via Sacra and remained at the foot of the cross, by all those who believed in him and worshipped him before; how would they now believe that this martyr would resuscitate? The question comes instinctively: if death is so terrible and if the laws of nature are so powerful, how could they be overcome? How could they be subjugated, if not even he, such as he was, could beat them: he who during his life ruled over nature with his will, exclaiming: 'Talita Kumi!' 'Rise, maiden!' and the young woman rose; saying to Lazarus: 'Lazarus, come out from there, I command you!' and Lazarus rose!...? Contemplating such a painting, we imagine nature in the form of an immense, rough, mute, merciless monster, or more exactly and speaking much more truly, no matter how strange it sounds, in the form of one of those very recent abominable construction machines that has mutely and indifferently crushed, devouredand spewed out a being that is infinitely precious, a being that is worth the whole Earth, which was without doubt created solely for his coming and descent onto it, onto Earth, this being! (...) If there are any people around the dead body (on the picture, no one appears) they must be experiencing the most terrible anguish and the most tremendous consternation, since that twilight at Calvary must be extinguishing all their hopes, not to mention all their convictions. And they must be leaving that place filled with dread, taking with them profound thoughts that they will never be freed from"13.

In the same novel, Dostoevsky again cites Holbein's painting, a reproduction of which was hanging on the wall of Rogozhin's house:This picture... this picture only serves to make many people lose their faith ${ }^{14}$.

It is possible that Dostoevsky may have shown the symptoms of Stendhal's syndrome on other occasions. In an article published in 1861 in the magazine that he was the chief editor of -The Time, entitled "Dobrolyubov and Art", he made it clear that he admired the ancient and Italian masterpieces, in particular the Apollo of Belvedere whose beauty he idealized: "a majestic and infinitely beautiful image" that engendered "a sensation of the divine" and was capable of causing a long-lasting "internal change" in the soul of those who contemplate this image ${ }^{15}$. 
According to the words of Anna Grigorievna, in Florence Dostoevsky "incessantly praised the famous bronze doors of the St John Baptistery. He would like to have a photographic reproduction at natural size of Lorenzo Ghiberti's masterpiece and, in particular, The Door of Paradise permanently within his gaze in his work office ${ }^{16}$.

Paintings played an important role in Dostoevsky's works, in his novels and in his journalistic articles. This is shown in three ways: the novels, the real paintings recalled and the pictorial compositions imagined. According to Jacques Catteau, when in front of Holbein's painting, Dostoevsky was transformed "as if nailed to the spot" with his face transfigu red with enthusiasm or convulsed with terro $r$ "like at the beginning of an epileptic crisis". The fascination with paintings lasted for long minutes and sometimes hours, and Dostoevsky, without womying about a possible fine, would bring a chair close so as to able to take in the picture better. His moods were ecstatic when viewing Titian's Christ Denied, Rafael's Sistine Madonna, Claude Lorrain's Acis et Galathe, Holbein's Madonna in Dresden, Rafael's St Cecilia in Bologna and Madonna of the Chair in Florence, or of mystical dread, like when viewing Dead Christ by Holbein in Basle ${ }^{17}$.

\section{DISCUSSION}

Comparing Dostoevsky's behavior in front of Holbein's painting (from Anna Grigorievna's testimony and Dostoevsky's own impressions left in the novel The Idiot, which was practically all written in Florence) with the behavior described by Graziella Magherini of the patients in front of celebrated works of art in Florence, there is the clear im$p$ ression that he presented the symptoms of Stendhal's syndrome during that visit to the museum in Basle. Upon contemplating the picture he remained in a state of ecstasy and perplexity for half an hour or more with fixed gaze, suspended respiration and profound emotion affection, until the time when he was removed from the room by his wife who feared an epileptic crisis. In Anna's opinion, he had the same facial expression that preceded his epileptic attacks, with which she was very familiar: so much so that when she re tu rned to the room, she felt that a reaction was starting that could have resulted in one of the innumerable epileptic crises that he presented and immediately she led him out of the room.

We cannot know if Dostoevsky would have had an epileptic crisis if he had remained in his ecstat- ic contemplation of the painting. Nor do we have information regarding any history of epilepsy among Dr Graziella Magherini's patients. She states that electroencephalogram examinations were not performed; these could have provided an additional contribution toward understanding the phenomena presented by these patients. In any event, among the personal histories of the patients attended and diagnosed as presenting Stendhal's syndrome at the Santa Maria Nuova hospital in Florence, significant data were collected: more than half of the patients were familiar with psychiatric institutions, i.e. they had had at least one previous contact with a psychiatrist or psychologist but had not necessarily followed therapy or been admitted to hospital. Psychiatric histories were commoner among those whose symptoms we re of mental nature (altered sense of reality and distorted perception) and not of physical nature (i.e. psychosomatic). It is possible that the writer's sensitive nature, as the great artist he was, and the presumption that he also had epilepsy of the temporal lobe, may have contributed in some way toward the symptoms described. However, it is not possible to exclude that Dostoievski's behavior on facing the picture by Holbein have not been a compleex partial epilepsy manifestation. There are innumerable indications of the fervent religiosity that Dostoevsky professed throughout his life.

Dostoevsky's breakup with Byelinsky itself reveals his unswaying religious beliefs.

As well as being a major symbolic personality within nineteenth-century Russian culture, Byelinsky was one of the most important figures at the outset of Dostoevsky's literary career. It was this critic's praise of the novel Poor People that caused the author's sudden fame in the 1840s, and Byelinsky took him under his wings not only in relation to literatu rebut also as a moral and spiritual mentor. Dostoevsky nurt u red great admiration and friendship for the critic. Nevertheless, this did not pro sper and Dostoevsky made a definitive break with him following Byelinsky's ironic references to Christ: "I am really moved when I look at him [Dostoevsky] [...]. Every time I mention the name of Christ, his face changes expression as if he were about to burst into tears"18. Al the indications are that this re action could have been provoked only by words that we re deeply offensive regarding Christ.

It is also relevant to cite the exact words of the famous letter Dostoevsky wrote to Fonvizin as soon as he left the Siberian prison: "If anyone were to 
prove to me that Christ is outside of the truth, and that in reality the truth is not within Christ, then I would rather stay with Christ than with the truth" ${ }^{19}$. Religious feelings exhacerbation is one of the personality traits in temporal lobe epilepsy as pointed by several authors following Geschwind e and Waxman in the seventies ${ }^{20-22}$. Dostoevsky call attention to that in several of his personages, as Alexey and the staretz Zossima in The brothers Karamasov. However, the most remarkable description of interictal personality traits in temporal lobe epilepsy appears in Prince Míschkin of The Idiot $^{23}$.

Dostoevski confessed countless times that the central fact in his whole life was the existence of God. It is possible that this fervent Christianity which informed his whole life sensitized him for his declaration upon viewing Dead Christ that this was an extremely humanized and anguished image of the dead Christ, without the transcendence generally involved in the pictorial representations of Christ made by other artists. It is this that probably motivated him to utter the famous phrase recorded by Anna Grigorievna and later on placed in the mouth of the character Prince Michkin in the novel: "Faced with a picture like this, a man could lose his faith" 14 .

In conclusion, the jottings in the diary of Dostoevsky's second wife, Anna Grigorievna, and Dostoevsky's own references to the painting Dead Christ by the German painter Hans Holbein in the novel The ldiot, are highly suggestive that, in front of this painting, Dostoevsky presented symptoms that coincide with those attributed to patients with Stendhal's syndrome or, in other words, exacerbated emotions, a kind of ecstasy and lack of reali- ty, ecstatic contemplation and physical malaise when viewing a work of art.

\section{REFERENCES}

1. Magherini G. La sindrome di Stendhal. 3. Ed. Milan: Ed. Ponte Alle Grazie, 2003.

2. Stendhal Rome, Naples et Florence. Paris: Éditions Gallimard, 1987:271-273.

3. Amâncio EJ, A epilepsia em Dostoiévski. Jornal Che Vuoi? (São Paulo), 1988;3:2-4.

4. Amâncio EJ, Zymberg ST, Pires MFC. Epilepsia do lobo temporal e aura com alegria e prazer. Arq Neuropsiquiatr 1994;52;2:252-259.

5. Amâncio EJ. Epilepsia na vida e na obra do escritor russo Fiodor Mikhailovitch Dostoievski: uma contribuição involuntária à neurologia. $\mathrm{O}$ Dendrito 2003;9:60.

6. Gastaut H. Fyodor Mikhailovitch Dostoevsky's involuntary contribution to the symptomatology and prognosis of epilepsy. Epilepsia 1978; 19:186-201.

7. Gastaut H. New comments on the epilepsy of Fyodor Dostoevsky. Epilepsia 1984;25;4:408-411.

8. Alajouanine T. Dostoievski's epilepsy. Brain 1963;86:114-133.

9. Alajouanine T. Littérature et épilepsie: l'expression littéraire de l'extase dans les romans de Dostoievski et dans les poèmes de Saint Jean de la Croix. In Dostoiévski, Paris: Cahier de l'Herne 1973;309-324.

10. Voskuil PHA. The epilepsy of Fyodor Mikhailovitch Dostoevsky (18211881). Epilepsia 1983;24:658-667.

11. Frank J. Dostoievski, The seeds of revolt 1821-1849. Princeton: Princeton University Press, 1979:239-257.

12. Frank J. Dostoiévski: the miraculous years, 1865-1871. Princeton: Princeton Univ Press, 1995;220-222.

13. Dostoïevskaïa AG., Carnets - Correspondance de F.M. Dostoïevski et A.G. Dostoïevskaïa. Vol. I, Moscow: “Radouga” Publishers, 1986;342-344.

14. Dostoiévski FM. O Idiota, Trad. by José Geraldo Vieira. Rio de Janeiro: José Olímpio Editora, 1967;415-416.

15. Dostoiévski FM: Récits, Chroniques et polémiques. Paris. Bibliothèque de La Plêiade, Ed. Gallimard, 1969;1052.

16. Dostoevskaja AG. Dostoevskij mio marito. Milano: Editora Tascabili Bompiani, 1977:133.

17. Catteau J. La creation littéraire chez Dostoiévski. Paris: Éditions Institut d'Études Slaves, 1978:37.

18. Frank J. Dostoievski: the miraculous years, 1865-1871. Princeton: Princeton Univ Press, 1995:229.

19. Frank J. Dostoievski: the stir of liberation, 1860-1865. Princeton: Princeton Univ Press, 1988:299.

20. Waxman SG, Geschwind N. Hypergraphia in temporal lobe in epilepsy. Neurology 1974;24:629-636.

21. Waxman SG, Geschwind N. The interictal behavior syndrome of temporal lobe epilepsy. Arch Gen Psychiatry 1975;32:1580-1586.

22. Trevisol-Bittencourt PC, Troiano AR. Síndrome de personalidade interictal na epilepsia do lobo temporal não-dominante. A rq Neuropsiquiatr 2000;58:548-555.

23. Souza LC, Mendes MFSG. Príncipe Liev Nikoláievitch Míchkin (“O Idiota", Fiódor Dostoevsky) e a síndrome de personalidade interictal na epilepsia do lobo temporal. Arq Neuropsiquiatr 2004;62:558-564. 